\title{
Boru Hattı Kamulaştırma Çalışmalarında Karşılaşılan Teknik, Ekonomik, Hukuki Sorunlar ve Çözüm Önerileri
}

\author{
Fatih İsCAN ${ }^{1}$, Fatih VARGELOĞLU ${ }^{2 *}$ \\ ${ }^{1}$ Konya Teknik Üniversitesi, Mühendislik ve Doğa Bilimleri Fakültesi, Harita Mühendisliği Bölümü, Konya \\ (fiscan@ktun.edu.tr) ORCID ID 0000 - 0002 - 0669 - 5830 \\ ${ }^{2} 6009-214$ Nolu Lihkab, Tokat \\ (fatihvargeloglu@gmail.com) ORCID ID 0000 - 0003 - 1635 - 4025
}

\begin{abstract}
Öz
Enerji nakil hattı projeleri, petrol boru hattı projeleri, tren yolları, otoyollar gibi kamu hizmetlerinin hayata geçirilebilmeleri için gerekli arazilerin ya kamu malı olması ya da kamuya mal edilmesi gerekmektedir. Ancak kamunun elinde bu projeler için gerekli araziler çoğu zaman ihtiyaçlara cevap verebilecek büyüklük ve uygunlukta bulunmamaktadır. Bu hizmetler için gereksinim duyulan ve kamuya ait olmayan taşınmazların kamuya mal edilmesi Anayasal güvence altındaki mülkiyet hakkını sınırlayıcı olan kamulaştırma işlemi ile gerçekleștirilebilmektedir. Kamulaştırma çalışmalarının uygulanması ise uzun ve detaylı işlemleri gerektiren bir süreçtir. Kamulaştırma işlemi gerçekleştirilirken hukuki, ekonomik ve teknik anlamda pek çok sorunla karşılaşılmaktadır. Kamu hizmetlerinin zamanında ve en ekonomik bir şekilde gerçekleştirilmesi için bu sorunların tespiti ve giderilmesi son derece önemlidir.

Bu çalışmada, Trans Anadolu Doğalgaz Boru Hattı (TANAP )projesi özelinde boru hattı kamulaştırma çalışmalarında karşılaşılan teknik, ekonomik ve hukuki sorunlar irdelenmiş, hata kaynakları araştırılmış ve bu sorunlar için öneriler getirilmiştir. Yapılan çalışma sonucunda, eski teknolojiyle üretilen kadastral paftalardan kaynaklanan hataların, taşınmazların bedel tespitinde karşılaşılan sorunların ve yasal mevzuattaki eksikliklerin kamulaştırma faaliyetlerini olumsuz etkilediği görülmüştür. Kamulaştırma faaliyetlerinin bu olumsuzluklardan etkilememesi için genel olarak teknik anlamda sayısal altlıkların tek bir sistemde oluşturulması, ekonomik anlamda taşınmaz değerlemesi ile ilgili ilke ve usullerin yeniden değerlendirilmesi, hukuki açıdan da yasal mevzuattaki boşluk ve eksikliklerin giderilmesi gerekmektedir.
\end{abstract}

Anahtar Kelimeler: Boru hattı, kamulaştırma, kamu yararı, mülkiyet hakkı, taşınmaz değerleme

\section{Technical, Economic, Legal Problems and Solution Suggestions in Pipeline Expropriation Studies}

\begin{abstract}
Required lands must be public property or be expropriated to make public services actual such as power transmission line projects, petroleum pipeline projects, train ways and highways. However, public often doesn't have required lands to meet needed size and suitability for these projects. Publication of nonpublic immovable properties needed for these services can be done by expropriation process limiting the property right which is under constitutional guarantee. The implementation of expropriation studies is a process that requires long and detailed procedures. In the expropriation process, many problems are encountered in legal, economic and technical fields. To carry out the public services in a timely and economic way, it is highly important to detect and solve these problems.

In this study, technical, economic and legal problems have been scrutinised encountered during the pipeline expropriation studies in the Trans Anatolian Natural Gas Pipeline (TANAP) project, error resources have been researched and suggestions for these problems have been introduced. As a result of this study, it has been seen
\end{abstract}

\footnotetext{
* Sorumlu Yazar
} 
that the errors caused by the cadastral sheets produced by the old technology, problems encountered in the price determination of immovable properties and the lacks in the legal regulations negatively affect the expropriation activities. For expropriation activities not to be affected by these negativities, in general, technically, the formation of the numerical bases in a single system, the reassessment of the principles and procedures about land valuation, fulfillment of legal gaps and shortcomings in legally are required.

Keywords: Pipeline, expropriation, public interest, property right, real estate valuation

\section{GİRIŞ}

Devlet ve kamu tüzel kişilerince, kamu yararının gerektirdiği hallerde, kamu hizmetlerinin veya yürütülebilmesi için, gerçek ve özel hukuk tüzelkişilerinin mülkiyetinde bulunan taşınmazların mülkiyet, kaynak veya irtifak haklarının bedellerini nakden ve peşin olarak veya Kamulaştırma Kanununda belirtilen hallerde eşit taksitlerle ödemek suretiyle ilgili idareler adına tesciline "Kamulaştırma" denilmektedir. Kamulaştırmanın amac1, kamusal projenin ihtiyacı olan gerçek ve özel hukuk tüzel kişilerinin mülkiyetinde bulunan taşınmazların, kamusal projenin ihtiyacına göre, mülkiyet, kaynak veya irtifak haklarının Anayasa ve yasaların ilgili hükümlerine uygun bir şekilde kamusal projeyi gerçekleştirecek olan devlet ve kamu tüzel kişilerine mal etmektir.

Kamu kurum ve kuruluşları, yapmakla yükümlü oldukları kamu hizmetlerini yerine getirebilmeleri amaciyla, özel veya tüzel kişilerde bulunan taşınmaz malların tamamını veya bir kısmını ayrıca irtifak hakkı olarak, kanun çerçevesinde kamulaştırabilmektedir. Kamulaştırılan taşınmazları belirli bir süre için ya da süresiz olarak kamu hizmetini yerine getirmek üzere kullanılabilmektedir.

Türkiye'de kamulaştırma ile ilgili temel mevzuat T.C Anayasasinin 35, 46, 47. maddelerinde düzenlenmiştir. T.C. Anayasasının 35. maddesi hükmünde "Herkes mülkiyet ve miras hakkına sahiptir. Bu haklar, ancak kamu yararı amaciyla sinırlandırılabilir" denilmekte, 46. maddesinin ilk fikrasinda ise "Devlet ve kamu tüzelkişileri; kamu yararının gerektirdiği hallerde, gerçek karşılıklarını peşin ödemek şartıyla, özel mülkiyette bulunan taşınmaz malların tamamını veya bir kısmını, kanunla gösterilen esas ve usullere göre, kamulaştırmaya ve bunlar üzerinde idarî irtifaklar kurmaya yetkilidir." denilmektedir. Anayasa maddelerinin uygulanmasina esas kanun ise 4650 Sayılı Yasa ile değişik 2942 sayılı Kamulaştırma Kanunu'dur. Ayrıca Kamulaştırma Kanunu'nun uygulanmasına ilişkin ilgili Bakanlıklar ve kamu kurumları tarafindan yayınlanan ikincil mevzuatlar da mevcuttur.

Kamu Kurum ve Kuruluşları belirtilen temel mevzuat ile birlikte kuruluş yasalarında kendilerine verilen yetkiler çerçevesinde de hareket etmek durumundadırlar. Ayrica özellikli projelerde, projenin amacina uygun olarak genel uygulamanın yanı sıra, projeye özgü bazı özel düzenlemeler de yapılabilmektedir (Akay ve Çiçek, 2005).

Kamulaştırma çalışmalarının uygulanması uzun ve detaylı işlemleri gerektiren bir süreçtir. Kamulaştırma işlemi genel olarak hukuki, ekonomik ve teknik olmak üzere 3 bileşenden oluşmaktadır. Aytaç 1987 yılında yaptı̆g 1 çalışmada kamulaştırmanın uygulamada sadece belirli hukuksal usulleri olan bir yönetsel işlem olmakla kalmayıp; mali, teknik yönleri yanında ayrıca psikolojik ve bazen siyasal etkileri ve tepkileri de olan bir soruna dönüşebileceğini ifade etmiştir.

4650 Sayılı Yasayla değiştirilmiş 2942 Sayılı Kamulaştırma Kanununun 7. maddesinde "Kamulaştırmayı yapacak idare, kamulaştırma veya kamulaştırma yolu ile üzerinde irtifak hakkı kurulacak taşınmaz malların veya kaynakların sınırını, yüzölçümünü ve cinsini gösterir ölçekli planını yapar veya yaptırır; kamulaştırılan taşınmaz malın sahiplerini, tapu kayd 1 yoksa zilyetlerini ve bunların adreslerini, tapu, vergi ve nüfus kayitları üzerinden veya ayrıca haricen yaptıracağ 1 araştırma ile belgelere bağlamak suretiyle tespit ettirir." ifadesi yer almaktadır. $\mathrm{Bu}$ çerçevede kamulaştırma işlemlerinin en önemli aşamalarından biride kamulaştırma planlarının ve dosyalarının üretilmesi sırasında yapılacak olan teknik çalışmadır.

Kamulaştırma Kanunu hükümlerine göre kamulaştırmanın hukuki sürecine başlanabilmesi için, hazırlanan kamulaştırma 
plan ve dosyalarının ilgili Kadastro Müdürlüklerince kontrol edilmesi ve kamulaştırma dosyaları içerisindeki kamulaştırma listelerine göre ilgili idarenin kamulaştırma kararını alması gerekmektedir.

Kamulaştırma devletin, kamu yararının gerektiği hallerde kamu gücünü kullanarak, özel kişilere ait taşınmazlara karşılığını ödemek suretiyle el koyması ve bunları kamu hizmetine özgülemesidir. Hiç kimse istenci dışında kamu yararı gerekçesiyle de olsa, karşıllğı da ödense taşınmazına el konulsun istemez. Çoğu kez manevi kaygıları maddi kayıplarının önüne geçmektedir. Öte yandan, ilgili kamu kurumu için kamulaştırma bedelleri projenin ederini önemli ölçüde artırmakta, kimi zamanda proje bedelinin üstüne çıkarmaktadır (Demirel, 2002; Sert, 2005).

Kamulaştırma sürecine bakıldığında, kamulaştırmanın bir takım işlemler zincirinden oluştuğu, bu zincirde bir halkanın eksik veya hatalı uygulanmasının kamulaştırma işleminin iptal edilmesine, hem idareyi hem de taşınmazı kamulaştırılacak olan malikleri olumsuz etkileyecek süreçlerin yaşanmasına neden olabileceği unutulmamalıdır. Yaşanabilecek olası olumsuzluklar sadece tarafları etkilemekle kalmayacak, kamulaştırma sonucu yapilacak olan kamu hizmetinin yapılamamasına veya gecikmeye uğramasına sebep olarak, daha başka sorunların ortaya çıkmasına da neden olabilecektir. Bu nedenle yapılacak işlemler bütün ayrıntıları ile birlikte dikkatli ve itinalı bir şekilde gerçekleştirilmelidir(Alkan, 2014).

Ülkemizde kamulaştırma sürecinin hukuki (Berberoğlu, 2004;Hayta, 2007; Eren, 2014; Çoban Atik, 2013; Demirbaş, 2014; Karaman, 2015;), ekonomik (Pehlivan, 2008; Tepe 2009; Ayten ve Çay, 2012) ve teknik (Sert, 2005; Uzer, 2010;Erdin, 2010;Ergüven, 2013; Yıldız, 2013; Dörtgöz, 2014, Çağla ve ark., 2016) yönden işleyiş ve sorunları ile ilgili pek çok çalışma gerçekleştirilmiştir. Göktepe 2010 yllındaki çalışmasında kamulaştırma kavramı, işlemin türleri ve yapılıș șekilleri ile mülkiyet hakkı üzerinde doğurduğu etki ve sorunlar olduğunu ifade etmiştir. Akay ve Çiçek 2005 yılındaki çalışmalarında, $1070 \mathrm{~km}$ uzunluğunda BaküTiflis-Ceyhan(BTC) Ham Petrol Boru Hatt1 Projesinde karşıllaşılan sorunların, kurumlardaki altyapı yetersizliği sorununun diğer birçok sorunun kaynağı olduğunu ve kamulaştırma çalışmalarına etkisinin büyük olduğunu ifade etmişlerdir.

$\mathrm{Bu}$ çalışmada, boru hattı kamulaştırma çalışmalarında teknik, hukuki ve taşınmaz değerlemesinden kaynaklanan uygulamada karşılaşılan problemler irdelenmiş, hata kaynakları araştırılmış ve öneriler getirilmiştir.

\section{MATERYAL VE YÖNTEM}

$\mathrm{Bu}$ çalışmanın ana materyalini, Boru Hattı Projelerinden, ülkemizde inşası halen devam etmekte olan ve uluslararası bir proje olan Trans Anadolu Doğalgaz Boru Hattı (TANAP) Projesinin kamulaştırma çalışmaları oluşturmaktadır. Projeye ait teknik, hukuki bilgi ve belgeler kullanılmıştır.

Azerbaycan'ın Hazar Denizi'ndeki Şah Deniz 2 Gaz Sahası ve Hazar Denizi'nin güneyindeki diğer sahalarda üretilen doğal gazın Türkiye'ye ve Avrupa'ya taşınması amaciyla hayata geçirilmiştir. TANAP, Türkiye-Gürcistan sınırında Ardahan ili Posof ilçesi Türkgözü köyünden başlayarak Ardahan, Kars, Erzurum, Erzincan, Bayburt, Gümüşhane, Giresun, Sivas, Yozgat, Kırşehir, Kırıkkale, Ankara, Eskişehir, Bilecik, Kütahya, Bursa, Balıkesir, Çanakkale, Tekirdağ ve Edirne olmak üzere 20 ilden(67 ilçe) geçecek; Yunanistan sınırında Edirne'nin İpsala ilçesinde son bulacaktır. 19 kilometresi Marmara Deniz geçişi olmak üzere kara ve deniz geçişi ile birlikte toplamda 1850 $\mathrm{km}$ uzunluğundaki proje, çoğunlukla kırsal alanlardan geçmekte ve kırsal ya da kentsel yerleşimlerde bulunan hiçbir yapıyı etkilememektedir(Şekil 1).

Kamulaştırma ve inşaat işleri; uluslararası standartlar gözetilerek yapılmakta olup projeden doğrudan ya da dolaylı olarak etkilenen ve ekonomik kayba uğrayan bireylerin kayılarının telafisi, önceden belirlenen kriterler çerçevesinde tazmin edilmesi temel prensibi esas alınarak yürütülmektedir(URL 1). 


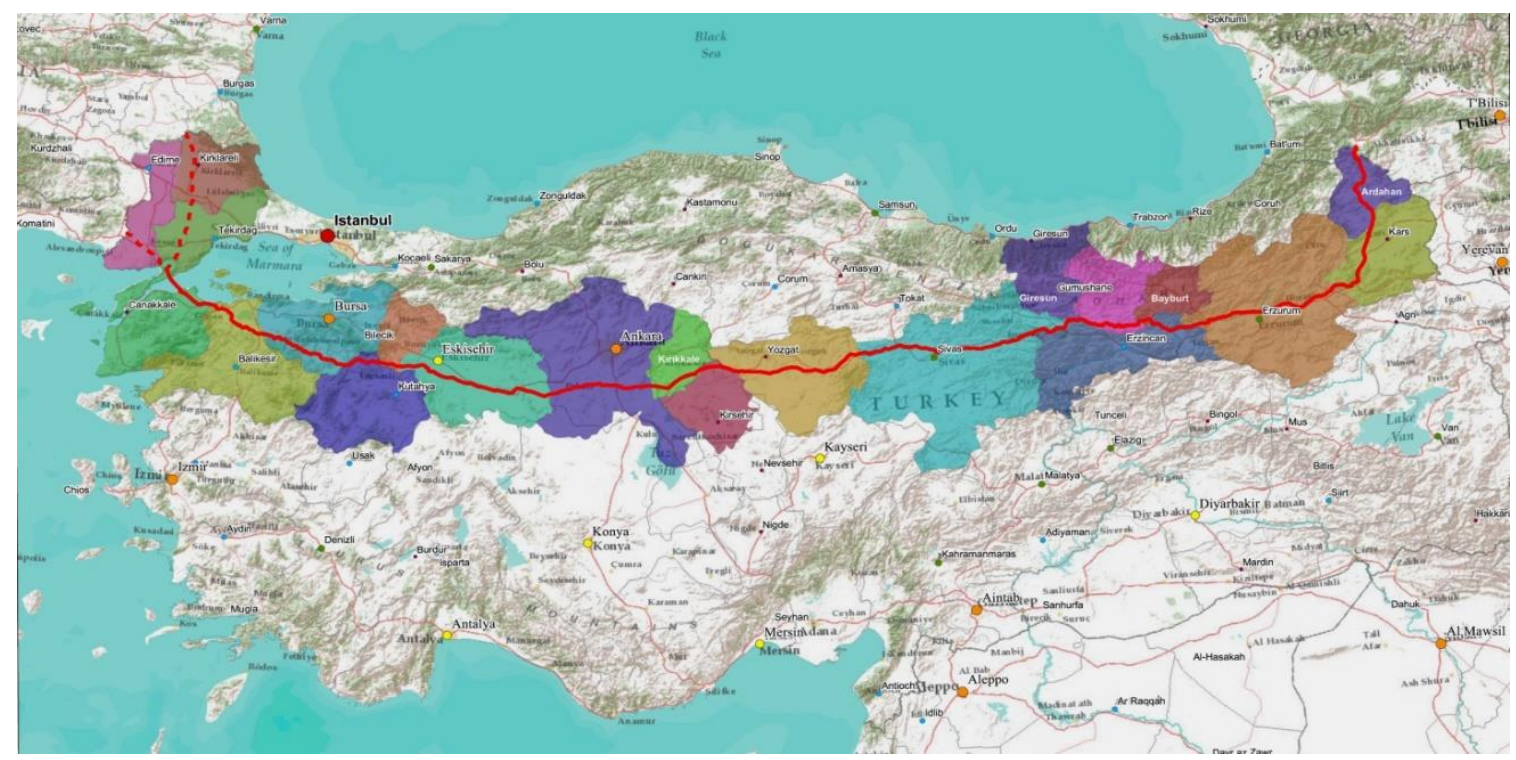

Şekil 1. TANAP'ın güzergahı (URL 2)

Projenin hukuki altyapısı 26 Haziran 2012 tarihinde İstanbul' da imzalanan "Türkiye Cumhuriyeti Hükümeti ile Azerbaycan Cumhuriyeti Hükümeti arasında Trans Anadolu Doğal Gaz Boru Hattı Sistemine İlişkin Hükümetler arası Anlaşma" ve eki Ev Sahibi Hükümet Anlaşması" ile oluşmuştur. Söz konusu Ev Sahibi Hükümet Anlaşması 26 Mayıs 2014 tarihinde tadil edilerek yeniden imzalanmış ve revize edilmiş haliyle 10 Eylül 2014 tarihinde TBMM tarafindan onaylanmıştır.

TANAP'ın inşaat çalışmaları 2015 yılının ilkbahar aylarında başladı ve 12 Haziran 2018'de Eskişehir'e kadar olan kısım tamamlanarak Türkiye'ye gaz akışı başlamıştır. Projede gaz akışının 4 aşamada artırılması tasarlanmaktadır. İlk aşamada 16 milyar metreküp taşıma kapasitesi yaratılarak Türkiye' ye 2018 yılının ikinci yarısında gaz akışı başlayacak ve yıllara göre artacak şekilde toplam 6 milyar metreküp ve Avrupa'ya 2020 yılının ilk çeyreğinde başlayacak ve yıllara göre artacak şekilde toplam 10 milyar metreküp gazı taşıması öngörülmektedir. Taşıma kapasitesinin 2023 y1lında 24 milyar metreküpe ve 2026 yılında 31 milyar metreküpe çıkarılması hedeflenmektedir. TANAP, Türkiye' de bu güne kadar yapılan en büyük çap ve uzunluğa sahip boru hattı projesi olacaktır (URL 2).

\section{BORU HATTI KAMULAŞTIRMA UYGULAMALARINDA KARŞILAŞILAN PROBLEMLER}

$\mathrm{Bu}$ bölümde boru hattı kamulaştırma çalışmalarında karşılaşılan problemler; teknik, taşınmaz değerlemesinden kaynaklı ve hukuki problemler ana başlıkları altında irdelenmiştir.

\subsection{Teknik Problemler}

2942 Sayılı Kamulaştırma Kanununun 7. Maddesine istinaden ilk olarak kamulaştırma planlarının oluşturulması gerekmektedir. Kamulaştırma planları oluşturulurken öncelikle kadastro müdürlüğünden kadastral veriler(paftalar, ölçü krokileri, sınırlandırma krokileri alan hesapları vs.) temin edilip tek tek irdelenmesi ve tespit edilen hata ve eksikliklerin yasal mevzuat çerçevesinde gerekli düzeltme işlemlerinin yapılması gerekmektedir. Kadastral veriler elde edildiği ve yapıldığı yıllara göre farklı teknik yöntemlerle üretildiğinden bazı teknik hatalar karşımıza çıkmaktadır. $\mathrm{Bu}$ problemler kamulaştırma sürecinde zaman kaybına ve yanlış değerlendirildiğinde kamulaştırma miktarlarının değişmesine sebep olacağından, kamulaştırma yapan idareyi veya mülkü kamulaştırılan vatandaşı ekonomik anlamda zarara uğratabilmektedir.

Kamulaştırma işlemlerinde karşılaşılan teknik problemleri; kadastral verilerden kaynakl1 teknik problemler, farklı kanunlar kapsamında 
yapılan uygulamaların kamulaştırma işlemi ile çakışması, Tapu sicilleriyle ilgili ve TAKBİS' ten kaynaklı problemler olmak üzere 3 grupta incelenebilir.

\subsubsection{Kamulaştırma çalışmalarında kadastral verilerden kaynaklanan teknik problemler}

\subsubsection{Kadastro esnasında yapılmış sinırlandırma hataları}

Sınırlandırma işlemi yapılırken birtakım hataların yapılmış olması olasıdır. Bu hatalar kamulaştırma projelerine ait kamulaştırma planları hazırlanırken karışımıza farklı şekillerde çıkmaktadır. Parsellerde kırıklar olduğu halde düz geçirilmiş ya da düz olduğu halde kırık noktalı geçirilmiş olması durumunda sinırlandirma hatasindan bahsetmek mümkündür. Fotogrametrik haritalara dayalı kadastro çalışmalarında, fotogrametrik paftadaki yanlış çizgilerin kullanılmasından dolayı hatalı sinırlandırma yapılabilmektedir.

\subsubsection{Kadastro esnasında yapılmış ölçme hataları}

Sınırlandırma işlemi yapılmış olan parseller kadastronun yapıldığ 1 tarihe göre prizmatik, takeometrik veya elektronik uzaklık ölçerler ile yer kontrol noktalarına dayalı olarak grafik, lokal veya ülke koordinat sistemine göre ölçümleri yapılmaktadır. Ölçümler yapılırken de çeşitli sistematik, düzensiz veya kaba hatalar yapılmaktadır. Bu tip hatalar zemin ile kadastro değerleri arasinda standart bir kayıklık veya dönüklük şeklinde karşımıza çıkmaktadır (Şekil 2).

Şekil 2'de görüleceği üzere bu hatalar giderilmeden kamulaştırmaya giren kısımların yüz ölçüm hesapları yapılacak olursa idare veya arazi sahiplerinin haksız bir kazanca veya zarara uğramasına sebep olunacaktır.

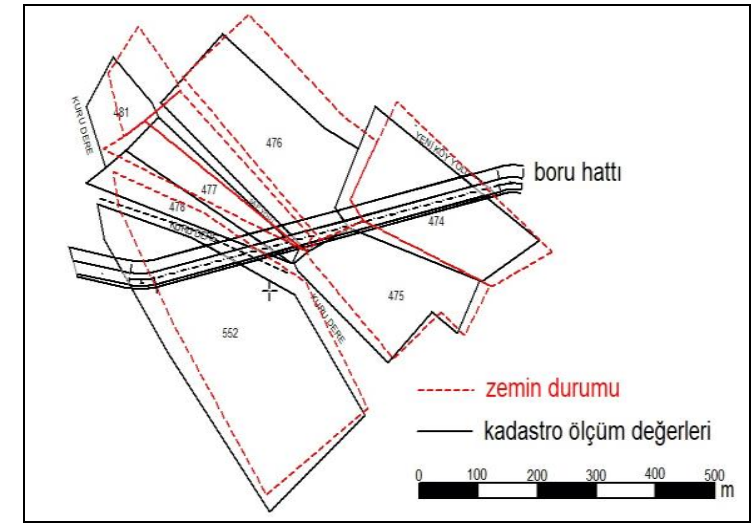

Şekil 2. Dönüklük ve kayıklığın olduğu ölçü hatas1

\subsubsection{Kadastro paftalarındaki tersimat hataları}

Kadastro ölçüm işlemleri yapılıp orijinal ölçü krokileri hazırlanan parseller, arazideki ölçü değerlerine göre altlıklara(kağıt, astrolon vs.) ölçekli bir biçimde çizilmesi işlemine pafta tersimatı denilmektedir. Tersimat hatasinın zeminle bir ilgisi bulunmayıp ölçü değerlerinin, paftasına doğru bir şekilde işlenememesinden kaynaklanmaktadır. Uygulamada tersimat hataları; parsel köşe noktalarının yanlış birleştirilmesi, noktaların açı ve mesafesinin yanlış tersim edilmesi, noktaların eksik tersimi, yer kontrol noktalarının hatalı tersimi şeklinde karşımıza çıkmaktadır.

\subsubsection{Yüzölçüm hesap hataları}

Kadastro çalışmaları esnasında yapılan yüz ölçüm hesapları tescile esas olup tapuya tescil edilmektedir. Sayısal olarak yapılan kadastro çalışmalarında koordinat değerlerinde bir hata olmadığı sürece yüz ölçüm hesap hatasına pek rastlanmamaktadır. Fotogrametrik ve grafik kadastro çalışmalarında ise pafta üzerinden planimetre denilen mekanik aletler yardımıyla pafta ölçeğine göre alan hesapları yapılmıştır. Yüzölçüm hesap hatalarının büyük bir kısmı bu yöntemle yapılan hesaplarında karşımıza çıkmaktadır.

\subsubsection{Kadastro paftaların üretim yönteminden kaynaklı kenarlaşma hataları}

Kadastro çalışmalarının başlangıç yıllarından bu tarafa geçen süreçte günün ölçü teknikleri kullanılarak çeşitli ölçeklerde kadastro paftaları üretilmiştir. Bunlar; grafik paftalar, klasik paftalar, fotogrametrik paftalar, sayısal paftalar şeklinde sınıflandırılabilir. 
Grafik yöntemle oluşturulan paftalar genellikle 1960'lı y1llardan önce üretilmiştir. Herhangi bir koordinat sistemine bağlı olmayan bu paftalarda, yoğun bir şekilde sınırlandırma, ölçü ve hesap hatalarına rastlamak mümkündür(Yıldız, 2013).

Günümüzde kamulaştırma projeleri sayısal olarak üretildiğinden grafik paftaların, benzerlik dönüşümü kullanılarak kamulaştırma projesinin koordinat sistemine dönüştürülmesi mümkün değildir. Ancak halihazır haritalarla ve ortofotolarla üst üste çakıştırılmak suretiyle ile dönüşümü sağlanabilir. Bu şekilde yapılan çakıştırmalarda ise kenarlaşma sorunları ile karşılaşılmaktadır.

Fotogrametrik yöntemle üretilen 1/5000 ölçekli paftalarda mülkiyet sınırları bir yazılım yardımıla parsel sinirlarının sayısallaştırılmasıyla oluşturulmaktadır. 1/5000 ölçekli bir haritada gözün ayıt etme gücü $0.2 \mathrm{~mm}$ olduğu düşünüldügünde $1-2 \mathrm{~m}$ ye varan sınır hataları ortaya çıkabilmektedir. Ayrıca dönüşümde kullanılan karelajlar uygun dağılımlı olmadığı takdirde dönüşümden kaynaklı hatalarda bunun üzerine eklendiğinde hata oranı artmaktadır. Bu sebepten dolayı da yan yana olan fotogrametrik paftalarda da dönüşümden ve sayısallaştırmadan kaynaklı kenarlaşma sorunlarıyla karşılaşılmaktadır (Şekil 3).

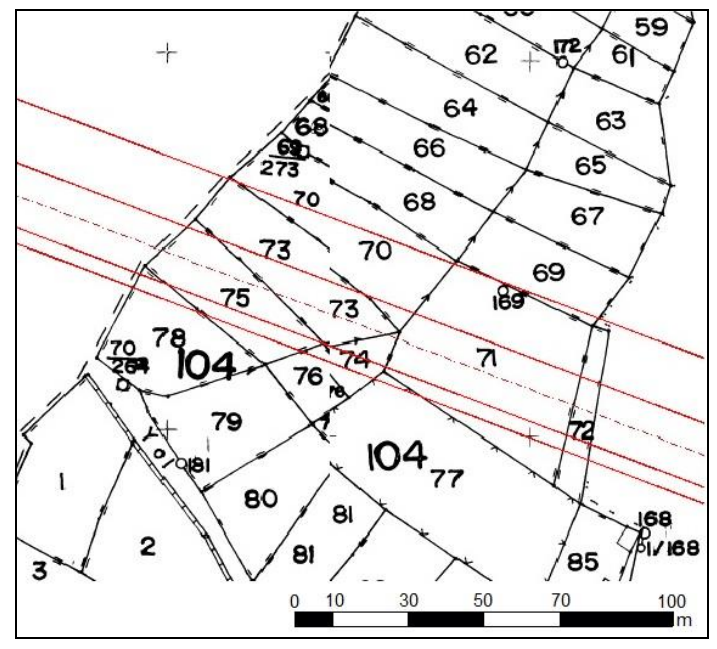

Şekil 3. 1/5000 ölçekli fotogrametrik paftalarda kenarlaşma sorunu

\subsubsection{Farklı kanunlar kapsamında yapılan uygulamaların kamulaştırma işlemi ile çakışması}

Kadastro yenilemesi ( 22/a) ve arazi toplulaştırma işlemlerinin kamulaştırma süreciyle aynı ana denk gelmeleri kamulaştırma sürecini olumsuz etkilemektedir. Her iki uygulamada da uygulamaya giren parselin tapu sicilinde köklü değişiklikler olması daha önce hazırlanan kamulaştırma planlarının tamamen değişmesine sebep olmaktadir.

\subsubsection{Kadastro yenileme uygulaması ile kamulaştırma işleminin çakışması}

22/a sürecinde parsel numaras1 ve parsel yüzölçümleri değişikliğe uğramaktadır. Kamulaştırma planlarının 22/a uygulamas1 tescil edilemeden önce hazırlandığ durumlarda kamulaştırma süreci tamamlanana kadar 22/a süreci de devam ettiğinden kamulaştırma planlarında hazırlanan alanlar ve parsel numaraları değişiklik gösterecektir. Kamulaştırma kapsamında gerek rıza-i alımlarda gerekse hükmen tescillerde parselin eski yüzölçümleri ve numaralarının yer alması tapuya tescilde sıkıntılar oluşturmaktadır. 22/a uygulamasında parselde yapılan değişiklikler kamulaştırma alanlarını değiştirdiği halde ilk durumda tescil edilen alanlar düzeltilmeden tapu sicilinde yeni oluşan parsellere aktarılmaktadır.

TANAP projesi kapsamında Ankara'nın Gölbaşı ve Polatlı ilçesinde kamulaştırma çalışmaları devam ederken 22/a uygulamasına başlanılmıştır. 22/a uygulamasının tescilinden önce etkilenen yaklaşık 418 parselin büyük bir kısmında rıza-en veya hükmen üst hakk1 tescilleri yapılmıştır. Bedel tespit ve tescil davaları (eski ada ve parsel numarası üzerinden aç1lan ve 27. madde blokeleri yapılan) devam ederken 22/a uygulamas1 tescillenen köylerde davalara müdahil olunarak, 22/a sonrası oluşan yeni parsel numarası ve alanlara göre mahkemeden karar çıkarılmış, ek blokeleri yapılmış, yeni kararlara göre hükmen tescilleri problemsiz yapılmıştır.

22/a uygulaması sonrası bazı parsellerde üst hakkı alanları büyük veya küçük değişimler geçirmiştir (Tablo 1). Bunlarla ilgili hak mahrumiyetinin giderilmesi maksadiyla ilave kamulaştırma yapılarak bu tür farklar giderilebilir. Burada ilave kamulaştırma için hazırlanacak tescil beyannamelerinde daha önceden tescil edilen üst hakkı alanlarının belirtilip yeni oluşacak üst hakkı alanı ile farkı kadar tapu harc1 ödenerek tapu kütügünde 
tescil edilip üst hakkı alanlarının güncel hale getirilmesi gerekmektedir.

Tablo 1. TANAP Ankara İli Polatlı İlçesi Muhtelif mahallerde 22/a uygulaması sonucu değişen kamulaştırma alanları

\begin{tabular}{|c|c|c|c|c|c|c|c|c|c|c|c|c|}
\hline \multicolumn{13}{|c|}{ ANKARA ILII POLATLI İLÇESI HÜKMEN TESCIL YAPILAN PARSELLER } \\
\hline \multirow[b]{2}{*}{\begin{tabular}{|l|} 
SIRA \\
NO
\end{tabular}} & \multirow[b]{2}{*}{ MAHALLE } & \multicolumn{4}{|c|}{ KADASTRO ONAYLI } & \multicolumn{4}{|c|}{ 22/A SONRASI } & \multicolumn{2}{|c|}{ FARK } & \multirow[b]{2}{*}{ DURUMU } \\
\hline & & $\begin{array}{l}\text { ESKi } \\
\text { ADA }\end{array}$ & \begin{tabular}{|l|} 
ESKi \\
PARSEL
\end{tabular} & \begin{tabular}{|l|} 
ESKi \\
TAPU \\
ALANI
\end{tabular} & $\begin{array}{l}\text { ESKi } \\
\text { DAIMi }\end{array}$ & $\begin{array}{l}\text { YENi } \\
\text { ADA }\end{array}$ & $\begin{array}{l}\text { YENI } \\
\text { PARSEL }\end{array}$ & $\begin{array}{l}\text { YENI } \\
\text { TAPU } \\
\text { ALANI }\end{array}$ & $\begin{array}{l}\text { YENi } \\
\text { DAIMi }\end{array}$ & $\begin{array}{l}\text { FARK } \\
\text { TAPU }\end{array}$ & $\begin{array}{l}\text { FARK } \\
\text { DAIMi }\end{array}$ & \\
\hline 1 & TÜRKKARSAK & 0 & 423 & 25125 & 1678,84 & 126 & 15 & 24788,99 & 1603,54 & $-336,01$ & $-75,30$ & HÜKMEN TESCIL \\
\hline 2 & TÜRKKARSAK & 0 & 259 & 139900 & 8671,56 & 126 & 6 & 146040,45 & 9082,69 & 6140,45 & 411,13 & HÜKMEN TESCIL \\
\hline 3 & TÜRKKARSAK & 0 & 222 & 223100 & 7168,37 & 116 & 12 & 231136,41 & 7280,87 & 8036,41 & 112,50 & HÜKMEN TESCIL \\
\hline 4 & KARAHAMZALI & 0 & 714 & 27037 & 2517,04 & 117 & 8 & 26412,58 & 2572,67 & $-624,39$ & 55,63 & HÜKMEN TESCIL \\
\hline 5 & KARAHAMZALI & 0 & 562 & 345000 & 5481,44 & 117 & 15 & 344178,15 & 5489,08 & $-821,85$ & 7,64 & HÜKMEN TESCIL \\
\hline 6 & KARAHAMZALI & 0 & 563 & 87000 & 1063,72 & 117 & 16 & 86996,48 & 1093,24 & $-3,52$ & 29,52 & HÜKMEN TESCIL \\
\hline 7 & KARAHAMZALI & 0 & 327 & 40675 & 618,55 & 117 & 18 & 39434,78 & 624,56 & $-1240,22$ & 6,01 & HÜKMEN TESCIL \\
\hline 8 & KARAHAMZALI & 0 & 524 & 91000 & 3004,64 & 120 & 2 & 93305,37 & 2909,39 & 2305,37 & $-95,25$ & HÜKMEN TESCIL \\
\hline 9 & KARAHAMZALI & 0 & 567 & 50056 & 1118,13 & 120 & 4 & 49965,03 & 1200,05 & $-90,97$ & 81,92 & HÜKMEN TESCIL \\
\hline 10 & KARAHAMZALI & 0 & 545 & 100000 & 213,20 & 120 & 53 & 102127,9 & 212,14 & 2127,90 & $-1,06$ & HÜKMEN TESCIL \\
\hline 11 & BAYBURT & 0 & 584 & 25000 & 610,57 & 125 & 12 & 24935,44 & 592,34 & $-64,56$ & $-18,23$ & HÜKMEN TESCIL \\
\hline 12 & BAYBURT & 0 & 580 & 86000 & 3034,98 & 125 & 14 & 86002,46 & 3023,45 & 2,46 & $-11,53$ & HÜKMEN TESCIL \\
\hline 13 & BAYBURT & 0 & 581 & 65100 & 2518,36 & 125 & 15 & 63385,79 & 2483,24 & $-1714,21$ & $-35,12$ & HÜKMEN TESCIL \\
\hline 14 & KIZILCAKIŞLA & 0 & 212 & 26250 & 2078,89 & 129 & 36 & 26828,15 & 2232,62 & 578,15 & 153,73 & HÜKMEN TESCIL \\
\hline 15 & KAYABAŞI & 0 & 462 & 73250 & 1519,60 & 179 & 59 & 73243,04 & 1405,86 & $-6,96$ & $-113,74$ & HÜKMEN TESCIL \\
\hline 16 & KIZILCAKIŞLA & 0 & 221 & 21500 & 430,94 & 129 & 19 & 21823,96 & 560,43 & 323,96 & 129,49 & HÜKMEN TESCIL \\
\hline 17 & KIZILCAKIŞLA & 0 & 466 & 34730 & 3872,85 & 129 & 31 & 36092,39 & 3931,96 & 1362,39 & 59,11 & HÜKMEN TESCIL \\
\hline
\end{tabular}

Uygulama sirasinda Polatli Kadastro Biriminde birkaç parsel için bu yapılmaya çalışılmış fakat yeni alan üzerinden tescilin yapılabilmesi için, eski alanın terkin edilip oluşan yeni alanın tescilinin yapılması ve yeni alan üzerinden tapu harcı ödenmesi istenmiştir. $\mathrm{Bu}$ durum kamulaştırmayı yapan idarenin mükerrer tapu harcı ödemesine sebep olmuştur (Şekil 4).

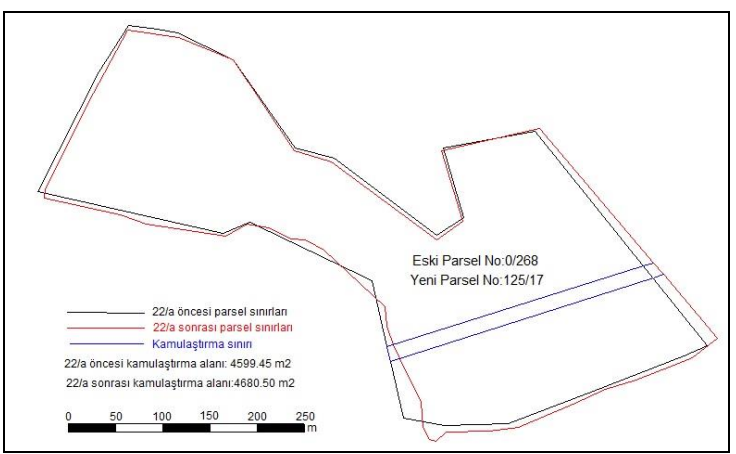

Şekil 4. 22/A Uygulamas1 Sonras1 Parsel

Durumu

\subsubsection{Arazi Toplulaştırması ile kamulaştırma süreçlerinin çakışması}

Arazi toplulaştırma çalışmalarında bütün kadastro sınırları değiştirilerek yeniden parseller oluşturulmaktadır. Arazi toplulaştırması sonrası durumda eski kadastro parseli yerinde kalsa da geometrik şekli değişeceğinden fiili durumdaki üst hakkı alanı da değişmektedir.

TANAP projesi kapsaminda Ankara İli Gölbaşı ilçesinde Bağiçi, Soğucak, Mahmatlı, Mahmatlıbahçe, Tepeyurt, Kırıklı, Karagedik ve Runkuş; Bala ilçesinde Yöreli ve Yeniköy olmak üzere güzergâh üzerinde kalan 10 mahallede arazi toplulaştırma çalışmaları devam etmektedir. Toplulaştırma yapılan bazı mahallelerde yapılan incelemede daha önceden tescil edilen üst hakkı alanlarının arazi toplulaştırması öncesi parsel numarası ile birlikte pasif duruma düştüğü, yeni planlara ve kütüklere aktarılamadığ 1 görülmüştür. İlgili köylerde 16 metrelik üst hakkı koridorunun köy bazında uzunluğu değișmeyeceğinden toplulaştırma sonrası toplam tescil edilecek üst hakkı alanı da köy bazında değişmemiştir.

Toplulaştırma sonrası parsellerin ada parsel numaraları, yüzölçümleri ve en önemlisi malikleri değişmektedir. $\mathrm{Bu}$ durumda bedel tespit ve tescil dava süreci devam eden parsellere açılan davaların geri çekilerek yeni duruma göre tekrar açılması ve dava sürecinde yeni maliklere tekrar tebligat gönderilmesi sürecin iyice uzamasına sebep olmaktadır. Burada kamulaştırmayı yapan idare zaman ve maddi açıdan zarara uğramaktadır. 


\subsubsection{Tapu sicilleri ve TAKBİS'ten kaynaklı problemler}

Rıza-en veya hükmen tescil yapılan üst hakkı tapu kütüğunde ayrı bir sayfaya bağımsız nitelikte kurulduğundan, ana taşınmaz üzerinde bulunan haciz, ipotek ve benzeri takyidatların sistem üzerinden üst hakkı sayfasına taşınmaması gerekmektedir. Tapu kütüklerinde yapılan kontrollerde bu tür takyidatlar taşınmadığı fakat TAKBİS sisteminde kütük elektronik ortamda saklandığı için parsellerde bu takyidatların üst hakkı sayfasına otomatikman taşındığ 1 tespit edilmiştir. Tapu personellerinin bu tür takyidatların taşınmaması veya düzeltilmesi hususunda TKGM tarafindan bilgilendirilmesi gerekmektedir.

Ayrıca rıza-en veya hükmen tescil edilen üst hakkı alanının bulunduğu parselde herhangi bir sebepten dolayı yapilan ifraz işlemi neticesinde, üst hakkı alanında değişiklik olsun veya olmasın, ifraz sonrası oluşan parsellere bu alan TAKBİS sistemi üzerinden otomatik taşınamamaktadır. Üst hakkı alanı ifraz öncesi parsel üzerinde pasif olarak kalmaktadır. Durumun ifraz sonrasında TAKBİS'deki 'veri düzeltme' sekmesi üzerinden düzeltilmesi işlemini de ilgili tapu personelleri her zaman yapmamaktadır.

TANAP kapsamında Kırıkkale ili Karakeçili ilçesi Yeşilevler mahallesinde, boru hattının geçtiği 997 ada 23 parselde $16 \mathrm{~m}$ koridor için yeşil renk ile gösterilen $3495,49 \mathrm{~m}^{2}$ üst hakk1 maliklerle rıza-i alım olarak tescil edilmiştir (Şekil 5). Bunun üzerine eklenen turuncu renk ile gösterilen blok vana istasyonu(BVS) mülkiyeti için 10. madde davası açılmış ve pembe renk ile gösterilen alan mülkiyeti alınacak kısım içerisinde kaldığı için buraya ödenen bedel dava sürecinde belirlenen bedel üzerinden mahsup edilmiştir. Dava gerekçeli karara çıktıktan sonra tescil için mülkiyeti alınan turuncu renk ile gösterilen BVS alanı için parselde yapılan ifraz sonucu 997 ada 23 parsel, 33 ve 34 parsel olarak ikiye bölünmüştür. 997 ada 34 parsel tapusu mahkeme kararına göre mülkiyeti BOTAŞ lehine olacak şekilde çıkmıştır. Kalan 997 ada 33 parselde, daha önceden kurulan üst hakkının dava sürecinde yapılan mahsuplaşması sonucu 2311,25 $\mathrm{m}^{2}$ olarak taşınması gerekirken, yapılan ifraz sonucu ana taşınmazda kurulmuş olan üst hakkının yeni parseller üzerine taşınmasını sistem sağlayamadığı gibi, alan üzerinde yapılması gereken azaltma işlemine de sistem müsaade etmemektedir. TAKBİS üzerinden konuyla ilgili güncelleme yapılması gerekmektedir.

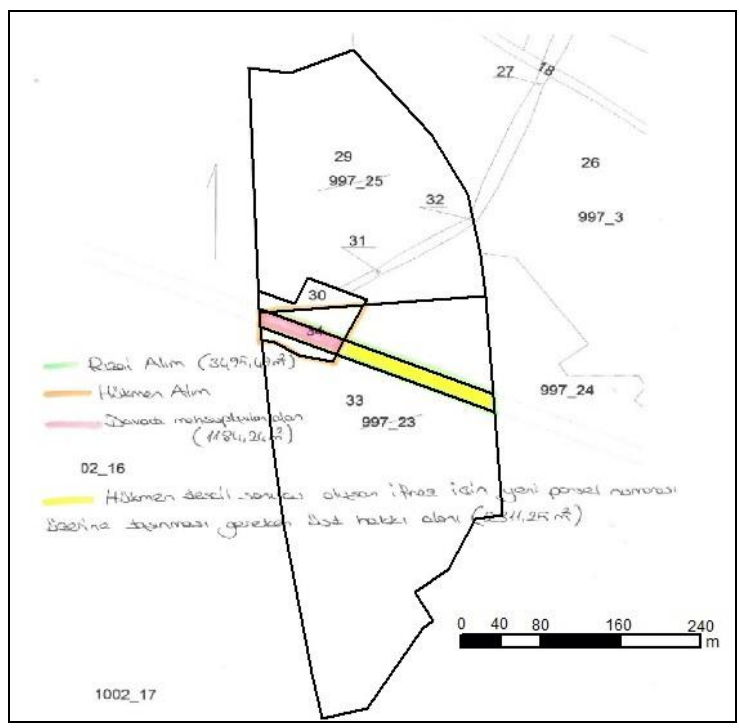

Şekil 5. Üst Hakkı Kurulu Parselin İfrazından Sonra Kalan Üst Hakkı Alanı

\subsection{Taşınmaz Değerlemeden Kaynaklı Problemler}

Ülkemizde birçok mal ve hizmetlerin değeri genelde rekabet şartları göz ardı edildiğinden tek değer ile belirlenir. Ancak ekonomik yatırım aracı olarak düşünülen taşınmazlar için böyle tek bir değer olmadığ 1 gibi, değerlerdeki değişim oranlarını da tahmin etmek oldukça güçtür. $\mathrm{Bu}$ nedenle özellikle ülkemizde aynı bir taşınmaza ait (vergiye esas değer, alımsatım değeri veya rayiç değer, istimlak değeri, adli yargıda bilirkişilerce belirlenen mahkeme değeri gibi) değişik değerler ile karşılaşılmaktadır. Oysa bir taşınmazın belli bir zaman periyodunda tek bir değeri olmalıdır. Farklı yaklaşımlar ile taşınmaz değeri tespit edilse dahi bu değerin kabul edilebilir bir aralıkta birbirine yakın olması beklenir. Bilimsel çalışmalara göre bu farkın \%15-20'yi geçmemesi gerekir (Açlar, ve Çağdaş, 2002).

Kamulaştırma Kanunu' nun satın alma usulünü içeren 8. maddesinin 2. fikrası her ne kadar ilgili kurum ve kuruluşlardan ve uzmanlardan görüş alınarak taşınmazın gerçek değerine en yakın değerin tespit edilmesi amaçlanmış olsa da kamulaştırmayı yapacak idareye kendi bünyesinden en az üç kişiden oluşan kıymet takdir komisyonu kurulması yetkisi vermiştir. Ancak idarelerin bünyesinden oluşturulacak 
klymet takdir komisyonunun kimlerden oluşacağı veya hangi teknik yeterliliğe sahip olacağı konularına değinilmemiştir. $\mathrm{Bu}$ şartlarda oluşturulacak kıymet takdir komisyonu uygulamada da yanlış kıymet takdiri yaparak ilgili idareyi veya vatandaş1 ekonomik anlamda sikıntıya sokmaktadır. Buna paralel olarak uzlaşma sağlanamadığından yargı yükü artacak ve süreç uzayabilecektir.

TANAP kapsamında Ankara ili Gölbaşı ilçesi Bağiçi Mahallesi ve Bala İlçesi Yöreli mahallelerinin tam sinırında boru hattı projesi geçmekte, birbirine bitişik muhtelif parseller yer almaktadır. $\mathrm{Bu}$ parsellerin konumu ve kıymet takdir komisyonunca belirlenen üst hakkı bedelleri Şekil 6'da verilmiştir.

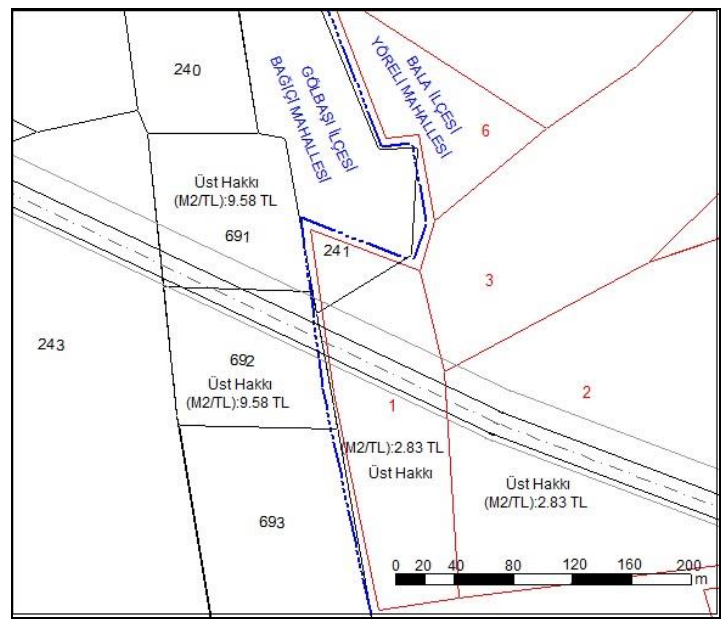

Şekil 6. Boru Hattının Geçtiği Farklı Mahallere Ait Bitişik Parseller

Şekil 6 incelendiğinde yaklaşı aynı konumda yer alan, topoğrafyası benzer olan ve tarımsal niteliği aynı olan kısacası değerleme açısından aynı objektif kriterlere sahip olan farklı ilçelerdeki parsellerin kıymet takdiri incelendiğinde; Bala ilçesi Yöreli mahallesindeki 1 ve 2 numaralı parsellerin üst hakkı birim fiyatı 2.83 TL iken, Gölbaşı İlçesi Bağiçi Mahallesindeki 691 ve 692 numaralı parsellerin üst hakkı birim fiyatının 9.58 TL'dir. Ayn1 konumdaki aynı tarımsal özelliklere sahip benzer ürünlerin yetiştirildiği arazilerin kıymet takdiri arasında yaklaşık 3 kat fark olduğu görülmektedir. Burada görünen sadece tapu kaydına göre ilçe farkıdır. Ankara ilinde Gölbaşı ilçesi Bala ilçesine göre daha popüler bir ilçedir. Tapu kaydında Gölbaşı yazması aynı konumdaki parseller arasında özelikle tarımsal nitelikli bir arazide 3 kat değer fark1 oluşturmaması gerektiği ortaya çıkmaktadır.

\subsection{Hukuki Problemler}

Boru hatt1 projelerinin kamulaştırma işlemlerinin önemli bir kısmını da hukuki işlemler oluşturmaktadır. Dolayısıyla hukuki işlemler gerçekleştirilirken de birçok problemle karşılaşmak mümkündür. $\mathrm{Bu}$ bölümde kamulaştırmanın hukuksal boyutuyla ilgili problemlere yer verilmiştir.

\subsection{1. İdari şerh (KK. 7. Md.) süre problemi}

7. Madde ile idare tarafından, şerh tarihinden itibaren altı ay içinde 10. maddeye göre "kamulaştırma bedelinin tespitiyle idare adına tescili isteğinde bulunulduğuna dair mahkemeden alınacak belge tapu idaresine ibraz edilmediği takdirde, bu şerh tapu idaresince resen sicilden silinir" denilerek idarelerin çok yavaş ve uzun süren kamulaştırma işlemlerinin yükünden kurtarılması ve şerh sebebiyle tasarrufu kısıtlanan vatandaşın mağduriyeti önlenmek istenmiştir (Çay ve Evren, 2007).

Ancak şerh den sonraki satın alma usulünde karşımıza çıkan uzlaşma komisyonunun belirlenmesi, tapu maliklerinin ve adreslerinin tespiti uzlaşma görüşmelerinin yapılması vs. süreçlerin tamamlanması çoğu zaman 6 ayı geçmektedir. Yani buradaki amaç gerçekleştirilememektedir. Ayrıca 7. madde şerhi olan bir taşınmazda tapuda yapılan bir işlemle malikin değişmesi durumu, tapu müdürlükleri tarafindan, idarelere çoğu zaman hızlı bir şekilde bildirilememektedir. $\mathrm{Bu}$ şekilde bir gecikmede malikin değişmesi o taşınmaz için 8 . madde sürecinin baştan yapilmasina sebebiyet vermektedir.

\subsubsection{Uzlaşma görüş̧melerinde pazarlık usulü ile satın almada karşılaşılan problemler}

Kamulaştırma Kanununun 8. maddesinin 4 ve 5. bendi satın alma usulü ile vatandaşla görüşülerek rıza-en alınmasını öngörülmektedir. Ancak Yöreli ve Bağiçi örneğinde görüleceği üzere birbirine bitişik mahallelerde kamulaştırma bedelleri arasında çıkan fark Yöreli Mahallesindeki vatandaşların riza-en alıma sicak bakmamalarına sebep olmuştur. Yöreli Mahallesinde rıza-i alım oranı yüzde \% 10'dur. Geriye kalan \% 90 lık kısım 
için ise Bedel Tespit ve Tescil Davası açılmak zorunda kalınmıştır.

Burada başka sorunda yukarda geçen 8 . maddenin 4. Bendinde uzlaşmaya davet mektubu yazılırken "pazarlık" kelimesi geçtiği için bu ibare mektuba da zorunlu olarak yazilmaktadır. Oysa uygulamada Kamulaştırma Kanunu' nun 8. maddesinin 5. fikrasına istinaden kıymet takdir komisyonu tarafından belirlenen fiyat dısıında rıza-i alım yapılamamaktadır. Uzlaşma görüşmelerinde vatandaş mektupta yazan "pazarlık" kelimesine istinaden serbest piyasa şartlarındaki gibi bir pazarlık yapılacağ algısına kapılmaktadır. Uzlaşma görüşmelerinde bu durumu, idarenin görevlendirdiği uzlaşma komisyonundaki kişiler vatandaşa izah etmekte zorlanmaktadırlar.

\subsubsection{Acele kamulaştırma dava sürecinde yaşanan problemler}

Kamulaştırma Kanunun 27. maddesine istinaden açılan acele kamulaştırma davalarında, mahkemece yedi gün içinde tespit edilecek değerin, idare tarafından mal sahibi adına bankaya yatırılarak o taşınmaz mala el konulmasinı talep etmektedir. Acele kamulaştırma davasında belirlenen bedel bir nevi işlerin başlayabilmesi için teminat yerine geçecek bir bedel olup çok hızlı bir şekilde belirlenmesi gerekmektedir. Burada acele kamulaştırma sürecinin 10 ve 15 . madde deki esaslar çerçevesinde yapılması 7 günlük sürenin uygulamada en az 1-2 ay sürmesine neden olmaktadır. Buda acele kamulaştırma işleminin amacının dışına çıkması anlamına gelmektedir. Bir nevi 10. madde uyarınca yapılan bedel tespit ve tescil davasinda yapilan iş ve işlemlerin nerdeyse tamamı acele kamulaştırma yargı sürecinde de yapılmaktadır. $\mathrm{Bu}$ durum boru hatt1 projelerinde binlerce parsel olduğu düşünüldüğünde aşırı bir yarg1 yükünü beraberinde getirdiği gibi yatırım projelerinin gecikmesine de neden olmaktadır. Konu ile ilgili olarak 11/11/ 2014 tarihinde talep edilen bir 27. madde davas1 31/12/2014 tarihinde karar verilebilmiştir.

\subsubsection{Bedel tespit ve tescil dava sürecinde yaşanan problemler}

Kamulaştırma kanunun 10. maddesinde, bedel tespit ve tescil davasına başvurduktan sonra mahkeme, başvuru tarihinden itibaren en geç otuz gün sonrası için duruşma gününü belirlemesi, bu duruşmada anlaşma sağlanamadığı takdirde en geç duruşma gününden 10 gün sonrası için keşif günü belirlemesi, bunun akabinde 30 gün sonras içinde tekrar duruşma günü belirlenmesi gerektiğinden bahsetmektedir.

Kamulaştırma Kanunu'nun 10/2 maddesinde idarenin başvuru tarihinden itibaren en geç otuz gün sonrası için duruşma günü belirlenmesi öngörülmüşse de, idarelerce yapılan büyük çaplı kamulaştırmalarda, bazen yüzlerce taşınmaz için duruşmaya hazırlık işlemlerinin ve tebligat işlemlerinin yapılması anılan süre koşuluna uyulmasını güçleştirmektedir. $\mathrm{Bu}$ halde kanunda öngörülen süreyi kanunun amacını gözeterek, "en klsa süre" olarak algilamak ve kamulaştırma bedelinin tespiti ve tescil davalarını öncelikli olarak ele almak gerekecektir. Aksi halde alelacele yapılacak iş ve işlemler sonucu davanın sağlıklı bir şekilde görülmesi engellenecek; gereksiz emek, zaman ve parasal kayıplara yol açılacak ve kanunun öngördüğü amaca şekli nedenlerle ulaşılamamış olunacaktır (Karagöl, 2009).

4650 sayılı kanunla değiştirilmiş 2942 sayılı Kamulaştırma kanunu 10. maddesinde anlaşma sağlanamadığı takdirde bedel tespit ve tescil davasının kamulaştırmayı yapan idarece açılmasını öngörmüştür. Kıymet takdir komisyonunun belirlediği bedel parsel malikince kabul edilmeyip bedel tespit ve tescil davasi yoluyla belirlenmesi durumunda mahkemece belirlenen bedel kiymet takdir komisyonunun belirlediği bedelden daha düşük olsa bile tüm dava giderleri kamulaştırma yapan idare tarafından karşılanmaktadır. $\mathrm{Bu}$ durum iki olumsuzluk sonucu doğurmaktadır.

- Boru hattı kamulaştırmaları yoğunlukla üst hakkı ve geçici irtifak şeklinde kurulduğundan kamulaştırma bedelleri mülkiyet kamulaştırması bedeli kadar yüksek bedeller olmamaktadır. $\mathrm{Bu}$ bedellerle dava masraflarını karşılaştırdığımızda dava masrafinın belirlenen bedelden 10-15 katı veya daha fazla bir bedele karşıllı geldiği uygulamada görülmektedir. Bir davaya ait mahkeme harc1, bilirkişi ücretleri, karş1 taraf vekil tayin etmişse avukat vekalet ücreti, tebligat ücreti hesaplandığında 2019 y1lı için 
yaklaşık 5-6 bin TL' yi bulmaktadır. Malik say1s1 arttığ takdirde bu rakam daha da fazlalaşmaktadır. Boru hattı projesi kapsamında muhtelif parsellere ait idarenin belirlediği 8 . madde bedelleri(kıymet takdir komisyonu), 27. madde bedelleri(acele kamulaştırma), 10. madde bedelleri(bedel tespit ve tescil davası) ve yaklaşık mahkeme masraflarının karşılaştırması yapılmıştır ( Tablo 2).

Tablo 2. Muhtelif parsellere ait idarenin belirlediği bedeller

\begin{tabular}{|c|c|c|c|c|c|c|c|c|}
\hline í & iLçE & KÖY & ADA & PARSEL & $\begin{array}{c}\text { IDARE } \\
\text { (KIYMET } \\
\text { TAKDiR } \\
\text { KOMISYONU) } \\
\end{array}$ & $\begin{array}{c}27 \text { MADDE } \\
\text { (ACELE } \\
\text { KAMULAŞTIRMA) } \\
\end{array}$ & $\begin{array}{c}\text { 10. MADDE } \\
\text { (BEDEL TESPIT } \\
\text { VE TESCIL } \\
\text { DAVASI) } \\
\end{array}$ & $\begin{array}{c}\text { YAKLAŞIK } \\
\text { MAHKEME } \\
\text { MASRAFLARI }\end{array}$ \\
\hline ANKARA & GÖLBAŞI & A & 115681 & 6 & $352.81 €$ & 386.00 も & $285.82 €$ & $5,500.00 €$ \\
\hline ANKARA & GÖLBAŞI & $B$ & 121398 & 40 & $108.08 €$ & 117.45 も & 79.00 も & $6,000.00$ も \\
\hline ANKARA & GÖLBAŞI & C & 121398 & 43 & 411.45 も & 447.10 も & $299.00 €$ & $5,300.00$ も \\
\hline ANKARA & GÖLBAŞI & D & 122751 & 11 & 186.37も & 203.07も & 96.57 も & $5,500.00$ Ł \\
\hline ANKARA & GÖLBAŞI & D & 122751 & 221 & $535.08 €$ & 583.02 も & $294.42 €$ & $5,700.00$ も \\
\hline ANKARA & GÖLBAŞI & $E$ & 0 & 234 & 808.53 も & 885.00 も & 379.70 छ & $5,400.00$ も \\
\hline
\end{tabular}

- 29. madde gereği dava sonucunda vatandaş haklıda çıksa haksızda çıksa veya bedel artsa da artmasa da vatandaştan hiçbir dava gideri ve avukat vekalet ücreti alınmadığından, piyasadaki serbest çalışan avukatlar kamulaştırma yapılan birimleri gezerek vatandaşa hiçbir ücret talep etmeyeceğini belirterek rıza-i alım yapılabilecek vatandaşları bile davaya ikna edip bu durumu kendilerine bir rant kapis1 haline getirebilmektedirler. Dolayısı ile bu şekilde de idare maddi ve manevi olarak zarara uğratılmaktadır.

Kamulaştırma Kanunu'nun 15. Maddesine göre bilirkişilerce bedel tespiti o günün verilerine göre yapılmaktadır. Taşınmaz sahibi davayı bir üst mahkemeye taşıyarak temyize başvurduğunda bir üst mahkemede güncel verilere göre fiyatın tekrar belirlenmesi gerekliliğine vurgu yaparak kararı bozmaktadır. Konuyla ilgili olarak bir Yargitay kararında kararın bozulması yönünde gerekçe '"4650 Sayılı Kanunla değişik 2942 Sayılı kanunun 10. maddesi gereğince açılan tespit ve tescil davalarında değerlendirmenin; aynı kanunun 15/ son maddesi uyarınca dava tarihi itibari ile yapılması gerekir. Belirtilen nedenle; davacı idarenin usuli kazanılmış hakkı gözetilerek dava konusu taşınmaza dava tarihi olan 2015 verileri esas alınarak değer biçilmesi gerekirken, bu husus gözetilmeden 2014 y1lı resmi verilerine göre değer biçen bilirkişi raporu doğrultusunda hüküm kurulması" şeklindedir. Buradan da görüleceği üzere 2015 y1lında görülen bir davada 2015 resmi verileri henüz ortada olmadığından 2014 yılı verilerine göre hazırlanan bilirkişi raporu tespit ve tescil davasında alınan kararın bozulmasina sebep olmaktadir.

\subsubsection{Devletin hüküm ve tasarrufu altındaki arazilerin edinimi ve bir idareye ait taşınmaz malın diğer idareye devrinde yaşanan problemler}

2942 Sayılı Kamulaştırma Kanunu 'nun 30. maddesi, devletin hüküm ve tasarrufu altındaki arazileri devir işlemlerinde kamulaştırmayı yapan idare ödeyeceği bedeli belirterek mal sahibi idareye başvuru yapar. Bu başvuruya 60 gün içinde cevap gelmezse idare Danıştay' a dava açar dava 2 ay içinde karar bağlanır. Taraflar bedelde anlaşamadiğı takdirde Danıştay kararının tebliğ tarihinden sonra 30 gün içinde K.K. 10 madde esaslarına göre işlemlere devam edilerek bedel tespit ve tescil davası açılır.

Uygulamada genellikle ilgili kurumlar 60 gün içinde kamulaştırmayı yapan idareye cevap verememektedirler. Bunun sebebi ise burada da kamulaştırmayı yapan idarenin teklif ettiği fiyatları değerlendirecek bilgi ve beceride personel olmayışıdır. Ayrıca kurumlardaki personeller karar almada kendine bir güvensizlik içinde olduklarından sorumluluk almaktan kaçınmaktadırlar. Bu sebeple ikinci bir alternatif olan yargıya iş yüklemektedirler. Dolayısıyla 30. madde kapsamında da çoğu zaman devirler yarg1 karariyla yapılabilmektedir. Zaten yoğun olan adliyelerdeki iş yoğunluğunu artırmak 
suretiyle hem zaman hem de ekonomik anlamda gerek idare gerekse devlet zarara uğramaktadır.

\subsubsection{Kamulaştırma hattının hazineye ait parselden geçmesi}

Hazineye ait taşınmazların kamulaştırma kapsamında devri işlemleri defterdarlık veya mal müdürlükleri ile iliği idare arasında olmaktadır. Buralarda çalışan personel zaman zaman sürecin uzamasına sebep olmaktadır. $\mathrm{Bu}$ sebeple de genellikle kamulaştırma yapan idare ilgili kurumdan 60 gün içinde cevap alamadığı için Danıştay kanalıyla kamulaştırma işlemlerini sürdürmektedir.

\subsubsection{Kamulaştırma hattının karayolundan geçmesi durumu}

Kamulaştırma hattının karayollarını kestiği durumlarda da Karayolları Genel Müdürlüğüne ait taşınmazlar üzerine inşaat yapılması hususunda da mevzuat açısından bir takım sıkıntılar çıkmaktadır. Bu tür sıkıntılarda ancak yargı yolu ile çözüme kavuşturulmaktadır.

TANAP Projesi'nin karayoluna denk gelen kısımlarında müstakil ve daimi üst hakkı ve geçici irtifak hakkı için KK. 30. madde kapsamında karayollarına başvurulmuştur. Karayolları Genel Müdürlüğü, talep edilen üst hakkı ve geçici irtifak hakkının emniyet sahası içinde kalmaması ve yolun alt kısmından geçmesini sebep göstererek talebi 30. madde kapsamında karşılanamayacağını beyan ederek başvuruya olumsuz cevap vermiştir. Konu ile ilgili olarak Danıştay' a açılmış olup dava ile devir sağlanabilmiştir.

\subsubsection{Kamulaştırma hattının demiryolundan geçmesi durumu}

Kamulaştırma hattının demir yoluna denk gelmesi durumunda da yine 30. madde hükümlerince uygulamaya yön verilmektedir. TANAP projesinin hızlı tren hattıyla kesiştiği bölümler için 30 . madde kapsamında TCDD(Türkiye Cumhuriyeti Devlet Demir Yolları ) İşletmesi Genel Müdürlüğüne başvuru yapılmış ancak projenin geçişiyle ilgili detayları isteyerek süreç sürüncemede bırakılmış, olumlu cevap alınamadığ 1 için Danıştay'a dava açmak zorunda kalınmıştır. Konu ile ilgili Danıştay kararında idarenin dava dilekçesine atıfta bulunulmuş olup dilekçedeki" Müvekkil idare araziler ile ilgili her türlü proje ve detay çizimlerini davalı idareye sunulmuş olmasına rağmen davalı idare ....tarihli ...sayıli cevabi yazıda "Ankara-İstanbul Yüksek Hizlı Tren hattına yapılacak dikey boru hattı geçişine ilişkin proje ve detay çizimlerle birlikte müracaat halinde gerekli çalışmalar yürütüleceğinden", bahisle çelişkili cevap vererek söz konusu parsel için talep edilen 3 yıllık geçici irtifak talebine hukuki dayanaktan yoksun gerekçelerle muvafakat etmemiştir." ifadesi dikkat çekmektedir. Danıştay BOTAŞ lehine karar vermiştir.

\subsubsection{Kısmi kamulaştırmada yaşan problemler}

Kamulaştırma işi, oldukça pahalı ve zor bir süreç olduğundan; kamu projeleri ya uygulanamamakta ya da planlanan sürede gerçekleştirilememektedir. Kamulaştırılan kısım amacı dışında kullanılamadığından kurumlar açısından kullanım esnekliği bulunmamaktadır. Projede amaç yalnızca taşınmazın ihtiyaç duyulan kısmının kamulaştırılması olduğundan hem parsel geometrisi bozulmakta, hem de örneğin hızlı tren projelerinde uzun mesafeler boyunca parselin iki tarafi arasında bağ koparılmaktadır. Böylece malik aleyhine zarara sebep olunmakta, çevre parsellerde oluşan değer artışlarının hem kamulaştırma maliyetlerini azaltacak hem de arazi spekülasyonunu engelleyecek şekilde bir mekanizmayla kamu ve malik yararına düzenleme anlayış ve öngörüsüne sahip olunmadığından, maliyetler yüksek seviyelere ulaşırken, mağduriyetlerde artmaktadır (Evren, 2012).

Bir taşınmaz malın kısmen kamulaştırılması durumunda, kamulaştırma dışında kısmın değerinde azalma olabilir veya dışta kalan kısım hiç bir işe yaramaz hale gelebilir. $\mathrm{Bu}$ durumlar genellikle kamulaştırma yapan idare ve vatandaş arasında problemlere yol açmaktadır. Yukarıda da belirtildiği gibi kamulaştırmayı yapan idareler sadece işine lazım olacak kısmı kamulaştırmak istemektedir. Ancak vatandaşın bazen bir yatırım projesi yapmak(örneğin besi ahırı, tavuk çiftliği gibi) için satın aldığı tarımsal nitelikli araziye kamulaştırma hattı denk gelebilmektedir. $\mathrm{Bu}$ durumda idareler, vasfi tarla olan bir arazinin kısmi kamulaştırma sonrası kalan kısmı ekilip biçilebileceği için almak istememektedir. $\mathrm{Bu}$ durumda 
kamulaştırma işlemi vatandaşın kendi yatırım projesini iptal etmesine sebep olabilmektedir. Burada kalan kısmın değer kaybının hesaplanarak kamulaştırma bedeline eklenmesi de vatandaşın işini çözememektedir. Benzer bir duruma Şekil 7'de yer verilmiştir. Şekildeki 121261 ada 33 nolu parselin sahibi çiftlik yatırımı yapmak için satın aldığı arazisinden boru hattı geçmesi sebebi ile kendi yatırım projesinden vazgeçmek zorunda kalmıştır. Şekilden de görüleceği üzere $B$ ve $C$ ile gösterilen kısım blok vana istasyonu ve yolu için mülkiyet kamulaştırması, turuncu renkli hat boru hattı inşaatı için üst hakkı alanı ve ENH için üst hakk1 vs. şeklinde parselin geometrisini bozacak şekilde kamulaştırma işlemleri yapılmıştır. Bunun yanında boru hatt1, enerji nakil hatt1 ve vana istasyonu parseli yeni yapı yapılamaz hale getirmiştir.

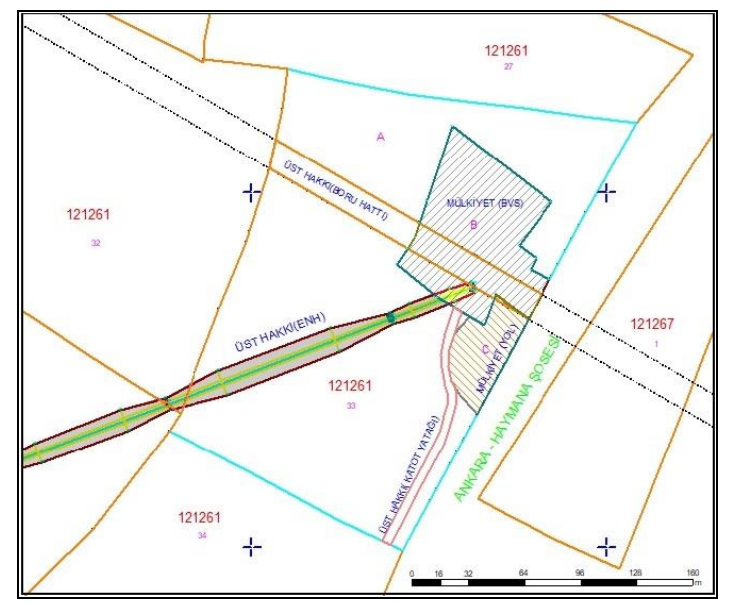

Şekil 7. Kısmi Kamulaştırmada Parsel Geometrisi

Kısmi kamulaştırma yapılan bir taşınmazın, kamulaştırılan kısmından arta kalan bölümü kullanılabilir halde değil ve yararlanılamayacak durumda ise, kalan kısım işlevini yitirdiği yani $\% 100$ değer kaybı oluştuğu için taşınmazın tamamen kamulaştırılması gerekir. Kamulaştırma Kanununun 12. maddesinin 5. fikrasina göre; taşınmaz maliki, kamulaştırma işlemine karşı idari yargıda iptal davası açmaması halinde, kamulaştırma kararının kendisine tebliğinden itibaren 30 gün içinde idareye yazılı başvuru yapmak suretiyle, taşınmazın kalan kısmının da kamulaştırılmasını talep edebilecektir (md.12/4). Bu suretle yapılacak kamulaştırma, yeni bir işlem (kamulaştırma) olmayıp önceki kamulaştırmanın devamı niteliğindedir. $\mathrm{Bu}$ bağlamda, Danıştay'ın verdiği bir kararda; "Bir kısmı kamulaştırılan taşınmaz maldan artan kısmı yararlanmaya elverişli bir durumda değilse, kamulaştırma işlemine karş1 idari yargıda dava açılmayan hallerde mal sahibinin en geç kamulaştırma kararının tebliğinden itibaren otuz gün içinde yazılı başvurusu üzerine, bu kısmın da kamulaştırılması zorunludur" hükmüne yer verilmiştir (URL 3).

\section{SONUÇLAR VE ÖNERILLER}

Kamulaştırmayı, devletin, kamu yararının gerektiği hallerde kamu gücünü kullanarak, özel kişilere ait taşınmazlara karşıllı̆ını ödemek suretiyle el koyması ve bunları kamu hizmetine sunması olarak nitelendirdiğimizde, mülkiyet hakkına zorla müdahale etmek gibi görünse de Anayasa ve yasalarda yer alması bakımından haksız bir fiil olmadığı Yargitay kararlarında görülmektedir.

Kamulaştırma, her ne kadar anayasa ve yasalarda dayanakları bulunsa da kişilerin malına bir bedel karşılığı el konulması olarak bakıldığında, maddi olarak insanlar tatmin edilmiş olsa bile(genelde tatmin olmak zorunda kalırlar), belki yüzyıllar öncesinde dedelerinden miras kalan arazinin kişilerin ellerinden zorla alınması manevi anlamda bir burukluk veya tatminsizlik oluşturmaktadır.

Kamulaştırmanın teknik sürecine bakıldığında problemlerin en büyük kaynağını kadastro verilerinin sağliklı olmamasından kaynaklandığı görülmektedir. Sadece kamulaştırma çalışmaları değil bu birimleri ilgilendiren kamusal projelerin hepsinde kadastro verilerinin sağlıksız oluşu projelerin sürecini uzatmakla birlikte hem idare hem de vatandaş açısından ekonomik zararlara sebebiyet vermektedir. Bir an önce ülkenin tamamı için, iyi bir planlama ile maksimum verim, minimum maliyet olacak şekilde sayısallaştırma, 22/a uygulaması, toplulaştırma ve imar uygulamaları ile doğru ve güncel konum verilerinin oluşturulması çok büyük önem arz etmektedir.

Ülkemizde aynı bölgede farklı içerikteki uygulamalar1 kapsayan projelerin (22/a uygulaması, arazi toplulaştırması, kamulaştırma vs.) aynı sürece denk gelmesi projelerde süre açısından gecikmelere, bu gecikmelerde proje maliyetinin artmasina sebep olmaktadır. Bu gibi aksaklıkların önüne geçilebilmesi için kurumlar arası koordinasyon 
merkezlerinin kurulması gerekli olup hayata geçirilecek projeler önem-maliyet ilişkisi göz önünde bulundurularak sıralama yapılmalıdır veya birlikte yürütülebiliyorsa ülke ekonomisine en yararlı olacak şekilde bütün tarafların en az mağdur olacağ 1 bir yol haritası çizilmelidir.

Tapu sicilinin tutulmasinda TAKBİS sistemine geçilmiş olması ülkemiz için çok önemli bir gelişmedir. Ancak kamulaştırma çalışmalarında bazı sorunlarla karşılaşıldığı ve kullanıcılarında sisteme tam olarak hakim olmadığı görülmüştür. TAKBİS' in ülkenin tüm ihtiyaçlarına cevap verecek şekle getirilmesi ve kullanıcıların sürekli eğitimlerle sistemi verimli bir şekilde kullanmaları sağlanmalıdır.

Ekonomik yatırım aracı olarak düşünülen taşınmazların değerlerinin tespiti zor olduğundan, özellikle ülkemizde aynı taşınmaza ait farklı değerler ile karşılaşılmaktadır. $\mathrm{Bu}$ değerler arasındaki farkl1lıklar giderilmelidir. Tapu ve Kadastro Genel Müdürlüğü teşkilatında "Taşınmaz Değerleme Dairesi Başkanlığı" kurulmuştur. $\mathrm{Bu}$ düzenleme taşınmaz değerleme konusunda ülkemiz adına çok güzel bir gelişmedir. Ancak bir an önce içi doldurularak kuruluş amacına uygun ve verimli bir hale getirilmelidir. Ayrıca, ülkemizde kamulaştırma yapan kurumların çoğunda taşınmaz değerleme konusunda uzman kişiler bulunmamaktadır. Kamulaştırma Kanununda kıymet takdir komisyonunu oluşturacak kişilerin niteliklerine de yer verilmelidir.

Bedel tespit ve tescil davalarında Kamulaştırma Kanunu'nun 29. maddesi gereğince taşınmazı kamulaştırılan vatandaştan hiçbir dava ücreti talep edilmemektedir. Tüm yargı giderleri ve avukat vekâlet ücretleri kamulaştırma yapan idare tarafindan karşılanmaktadır. Bu durum serbest çalışan bazı avukatların vatandaşı etkileyerek rıza-i alıma yaklaşmamalarına sebep olmaktadır. Sadece kamulaştırma davalarına özel olarak asgari avukatlık ücreti(2019 y1lı için yaklaşık 2700 TL) çok düşürülerek cazip olmaktan çıkarılmalıdır.

Kamulaştırma güzergâhı üzerinde gerek özel mülkiyete ait gerekse kamu mallarının edinimi yasal süreç içerisinde istenilen zaman diliminde gerçekleşememektedir. Bunun en büyük sebeplerinden biri Bedel Tespit ve Tescil davalandır. Ülkemizde kamulaştırma işılemlerinin yargı ayağında da ayrı bir uzmanlık alanı olması gerekmektedir. Yani nas1l baz1 illerimizde Kadastro mahkemesi varsa Kamulaştırma Mahkemeleri de kurularak yarg1 ayağı da uzmanlaştırılmalıdır. Kamulaştırma mahkemeleri bünyesinde, Taşınmaz Değerleme Uzmanı, Harita Mühendisi, İnşaat Mühendisi, Mimar, Şehir Plancıs1, Ziraat Mühendisi ve kamulaştırma yapılacak birimin muhtarının da katılabileceği bir birim oluşturulmalı, davalar için gerekli bedel tespitlerini bu birim yapmalıdır.

Kamulaştırma Kanununun 27. Maddesine göre idarenin istemiyle mahkemece 7 gün içinde o taşınmaza el konulabilmesine rağmen, uygulamada bu süre 1-2 ay sürebilmektedir. Yatırımlarını gecikmemesi için Acele kamulaştırma işlemi 7 gün içinde tamamlanmalıdir.

Kamulaştırma Kanunu 30. madde kapsamına giren devletin hüküm ve tasarrufu altındaki arazilerin devri konusunda da 60 gün sinırı kaldırılmalıdır. Devir hemen yapılmalı bedel ise devir sonrasına birakılmalıdır. İdari sorunlar için ise kurumlar arası koordinasyon merkezleri devreye girmelidir.

Boru hattı kamulaştırmaları çoğunlukla üst hakkı ve geçici irtifak şeklinde kurulmaktadır. İrtifak yüzölçümü küçük olduğundan dolayı çok küçük kamulaştırma bedelleri belirlenmektedir. Ancak, bu tür taşınmazlar için açılan davalarda dava masrafları kamulaştırma bedellerinden çok fazla çıkmaktadır. Böyle durumlarda kamulaştırmayı yapan idarelerce bedelde esneklik sağlayıp, taşınmaz sahiplerinin dava yolu yerine satın alma usulünü tercih etmeleri sağlanmalıdır.

Kısmi kamulaştırmalarda ise, geriye kalan kısım idare ve vatandaş açısından sorunlara neden olmaktadır. Burada geriye kalan kısmın kullanılıp kullanılamayacağı göreceli bir kavram olup idareler ve vatandaş arasında soruna neden olmaktadır. Vatandaş mağduriyetinin önlenmesi için çok kritik durumlarda taşınmazın tamamı kamulaştırılmalı, kurumun ihtiyacı dışında kalan kısım talep eden başka bir vatandaşa satış yapılabilmelidir. 
Kamulaştırma işlemi gerek hukuki gerekse teknik yönden birçok işlemi kapsayan uzun bir süreç ve çok maliyetli bir çalışmadır. $\mathrm{Bu}$ nedenle arazi içerikli bir kamusal projenin arazi ediniminde ilk olarak kamulaştırmaya başvurmak yerine daha az maliyetli ve vatandaşında kabul edebileceği, ihtiyaçlara en uygun çözümler oluşturabilecek, kırsal alanlarda arazi toplulaştırması projeleri, kentsel alanlarda ise imar ve kentsel dönüşüm projeleri yaygınlaştırılmalıdır.

\section{KAYNAKÇA}

Açlar, A. ve Çağdaş, V., (2002). Taşınmaz (Gayrimenkul) Değerlemesi, 1. Bask1, TMMOB Harita ve Kadastro Mühendisleri Odas1, Ankara.

Akay, Y. ve Çiçek, Y., (2005). Uygulamalı Kamulaştırma Tekniği, Harita ve Kadastro Mühendisleri Odası, Ankara.

Aytaç, F., (1987). Kamulaştırma Ve Uygulamada Karşılaşılan Sorunlar, Amme İdaresi Dergisi, Cilt: 20 Sayı: 2, Ankara.

Ayten T. ve Çay T., (2012). Problems Occured from Nationalization of Long-distance Line Projects, FIG Working Week 2012, Rome, Italy,

Berberoğlu, A., (2004). Avrupa İnsan Hakları Mahkemesi Kararları Işı̆̆ında Kamulaştırma Kavramı ve Türkiye Uygulaması, Yüksek Lisans Tezi, Gazi Üniversitesi. Sosyal Bilimler Enstitüsü, Ankara.

Çağla H., İşcan F., ve Hekim B., (2016). Kamulaştırma Kanunun 27.Madde Uygulaması (Acele Kamulaştırma), Selçuk Üniversitesi Teknik-Online Dergi, Cilt:15,Sayı:1.

Çay T., ve Evren N., (2007). Kamulaştırma Uygulamalarında Uzlaşma Başarımı, TMMOB Harita ve Kadastro Mühendisleri Odası, 11. Türkiye Harita Bilimsel ve Teknik Kurultayı, Ankara.

Çoban Atik , A., (2013). Kamulaştırmada Yargısal Denetim, Doktora Tezi, S.Ü. Sosyal Bilimler Enstitüsü, Konya.

Demirbaş, M., (2014). İstanbul İçme Suyu Havzalarında Uygulanan Kamulaştırma Çalışmalarının İdare Ekonomisi Açısından İncelenmesi, Yüksek Lisans Tezi, Bahçeşehir Üniversitesi, Fen Bilimleri Enstitüsü, İstanbul.

Demirel, Z., (2002), Kamulaştırma, Yıldız Teknik Üniversitesi Basım-Yayın Merkezi, İstanbul.

Dörtgöz, G. Ö., (2014). Yeni Tüzüğe Göre Tapu İşlemleri, Bil Ofset, Ankara.

Erdin, E. O., (2010). Kamulaştırma Bilgi Sisteminin Oluşturulması: Musabeyli
Barajı Örneği, Yüksek Lisans Tezi, Erciyes Üniversitesi, Fen Bilimleri Enstitüsü, Kayseri.

Eren, A., (2014). Türkiye'de Kamulaştırmasız El Atma Kavramı ve Davaları, Yüksek Lisans Tezi, Kadir Has Üniversitesi, Sosyal Bilimler Enstitüsü, İstanbul.

Ergüven, Ö. C., (2013). Kamulaştırma Kanununa Göre Kamulaştırmada Satın Alma Usulü, Yüksek Lisans Tezi, Marmara Üniversitesi. Sosyal Bilimler Enstitüsü, İstanbul.

Evren, N., (2012). Türkiye'de Kamulaştırma Çalışmaları İçin Alternatif Yaklaşımlar, Doktora Tezi, S.Ü. Fen Bilimleri Enstitüsü, Konya.

Göktepe, H. S., (2010). Türk Hukukunda Kamulaştırma-Kamulaştırmasız El Atma ve Eşya Hukuku Yönünden Sorunları, Yüksek Lisans Tezi, İ.Ü. Sosyal Bilimler Enstitüsü, İstanbul.

Hayta M.A., (2007). Kamulaştırma Davaları, Yüksek Lisans Tezi, Ankara Üniversitesi Sosyal Bilimler Enstitüsü, Ankara.

Karaman, B., (2015). Acele Kamulaştırma, Yüksek Lisans Tezi, Ankara Üniversitesi, Sosyal Bilimler Enstitüsü, Ankara.

Pehlivan, C., (2008). Kamulaştırmada Bedel Tespiti, Yüksek Lisans Tezi, İ.K.Ü. Sosyal Bilimler Enstitüsü, İstanbul.

Sert A., (2005). Kamulaştırma Amaçlı Arazi Toplulaştırma, Yüksek Lisans Tezi, Y.T.Ü. Fen Bilimleri Enstitüsü, İstanbul.

Tepe, S., (2009). Kamulaştırma Ve Mülkiyet İlişkisinin İrdelenmesi Üzerine Bir Araştırma, Yüksek Lisans Tezi, S.Ü. Fen Bilimleri Enstitüsü, Konya.

Uzer, Z.Y., (2010). Kamulaştırma Uygulamalarında Hazine Arazilerinden Yararlanma Ve Sit Alanlarına İlişkin Uygulamaların İncelenmesi, Yüksek Lisans Tezi, K.T.Ü. Fen Bilimleri Enstitüsü, Trabzon.

Yıldız, O., (2013), Türkiye Kadastrosunun Mevcut Durumu Ve Çok Amaçlı Kadastroya Yönelik Yeni Yaklaşımlar, Doktora Tezi, K.T.Ü. Fen Bilimleri Enstitüsü, Trabzon.

URL 1. Trans Anadolu Doğal Gaz Boru Hattı Projesi (Tanap) Arazi Ediniminde İlave Haklar Ve Ekonomik Destekler Bilgilendirme Broşürü. https://www.tanap.com/store/file/files/TAN AP_AraziEdiniminde_ilavehaklar-

DestekFonu_Brosuru_2017_web. pdf [Erişim Tarihi:12.11.2018].

URL 2. Trans Anadolu Doğalgaz Boru Hattı Projesi Bilgi Notu, https://www.tanap.com/store/ file/common/81e3e4dc104e1717d6ad620de 3752257.pdf [Erişim Tarihi:12.11.2018].

URL 3. https://tr.themisa.com/makale/414-kismikamulastirmada-yasanan-sorunlar [Erişim Tarihi: 04.11.2018]. 